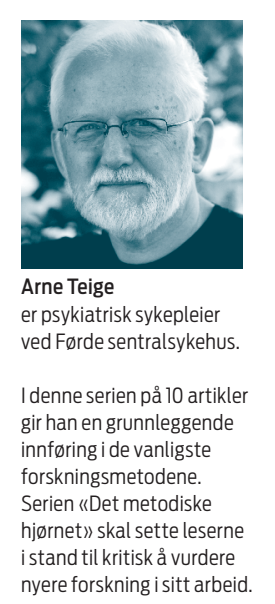

\section{Viktig å se variasjon}

Sist beskrev jeg «gjennomsnittet»: den tallverdien som best representerer ei gruppe og en tilstand. Denne gangen tar jeg for meg hvordan vi kan sammenfatte variasjonen i målinger.

V i har målt kroppstemperaturen hos ei gruppe friske voksne, har lagt sammen alle temperaturene, og deretter delt med antall målinger. Resultatet er blitt $37,0^{\circ} \mathrm{C}$. Hvordan vurderer vi dette?

Ulike målinger kan gi samme gjennomsnittsverdi. Tabell 1 viser dette poenget. De tre gruppene har alle samme aritmetiske gjennomsnitt, tross innbyrdes ulikhet. Gjennomsnittsverdien sier derfor ikke nok. Vi må også beskrive variasjonen.

\section{Temperatur hos friske voksne}

\begin{tabular}{|l|r|r|r|}
\hline Temperatur & Gruppe A & Gruppe B & Gruppe C \\
\hline 1 & 37,0 & 36,4 & 36,4 \\
\hline 2 & 37,0 & 36,6 & 37,3 \\
\hline 3 & 37,0 & 37,0 & 37,6 \\
\hline 4 & 37,0 & 38,0 & 36,7 \\
\hline
\end{tabular}

\section{Målingene}

Målingene i gruppe A kan være rette, men fremstår «mistenkelig» ensarta. Vi ville forvente litt variasjon. Målingene i gruppe B og C ser bedre ut, nettopp fordi verdiene er mer spredt. En måleverdi peker seg ut: person B4 har 38,0. Er dette en «normal variant», har vedkommende feber, eller finner vi andre forklaringer? (Dersom vi mistenker «feber», må målingen forkastes, siden gruppa vi undersøker er «friske voksne».)

Vi har få målinger. Hadde vi 1000, og fant at de varierte like lite som i gruppe A, ville vi blitt som apostelen Thomas: tvilende. Så stabile er aldri ei gruppe målinger! Derimot ville vi forvente å finne noen få personer med kroppstemperatur på 38,0, som person B4.

Rent intuitivt kan en vurdere hvor spredte målingene er ved se på den minste og den største verdien. Trekker man den laveste verdien fra den høyeste, får range).

Sammenligner vi hver måling med gjennomsnittsverdien, måler vi avviket (eng. deviation). For små grupper målinger er dette oversiktlig. Men hvordan skal vi sammenfatte avviket for 1000 målinger? En løsning med «gjennomsnittlig avvik» hjelper oss ikke, siden summen av de individuelle avvikene alltid er null.

Statistikerne har løst dette ved en «omvei» som kalles variansen. Den fører frem til standardavviket, det viktigste spredningmålet. Standardavviket oppgis rutinemessig i forskningsartikler. Standardavviket er alltid i samme måleenhet som de opprinnelige målingene.

\section{Potens og kvadratrot}

Jeg bruker stjerne som gangetegn (multiplikasjonstegn). I stedet for kolon bruker jeg skråstrek som delingstegn (divisjonstegn), slik:

Multiplikasjon: $2 \times 2=2 * 2=4$

Divisjon: $4: 2=4 / 2=2$

Regneoperasjonen «å gange et tall med seg selv» heter «å opphøye i potens». Multipliserer en tallet 2 med seg selv, opphøyer en 2 «i andre potens».

Opphøye 2 i andre potens: $2^{2}=2 * 2=4$.

«Ørepynten» (dvs. det lille totallet) viser hvor mange ganger tallet skal multipliseres med seg selv.

Den motsatte regneoperasjonen, hvor en finner hvilket tall som ganget med seg selv gir det tallet vi har, kalles «å trekke ut kvadratrota av».

Kvadratrota av $4: \sqrt{ } 4=2$ fordi $2 * 2=4$.

Oppskrift på varians (lett forenklet)

, Finn avvikene ved å trekke hver måling fra gjennomsnittsverdien

> Multipliser (gange) hvert avvik med seg selv

, Legg sammen alle verdiene i punkt 2

, Del (divider) resultatet i pkt. 3 på antall målinger.

Resultat: Variansen. man variasjonsbredda for målingene (eng. , Variansen

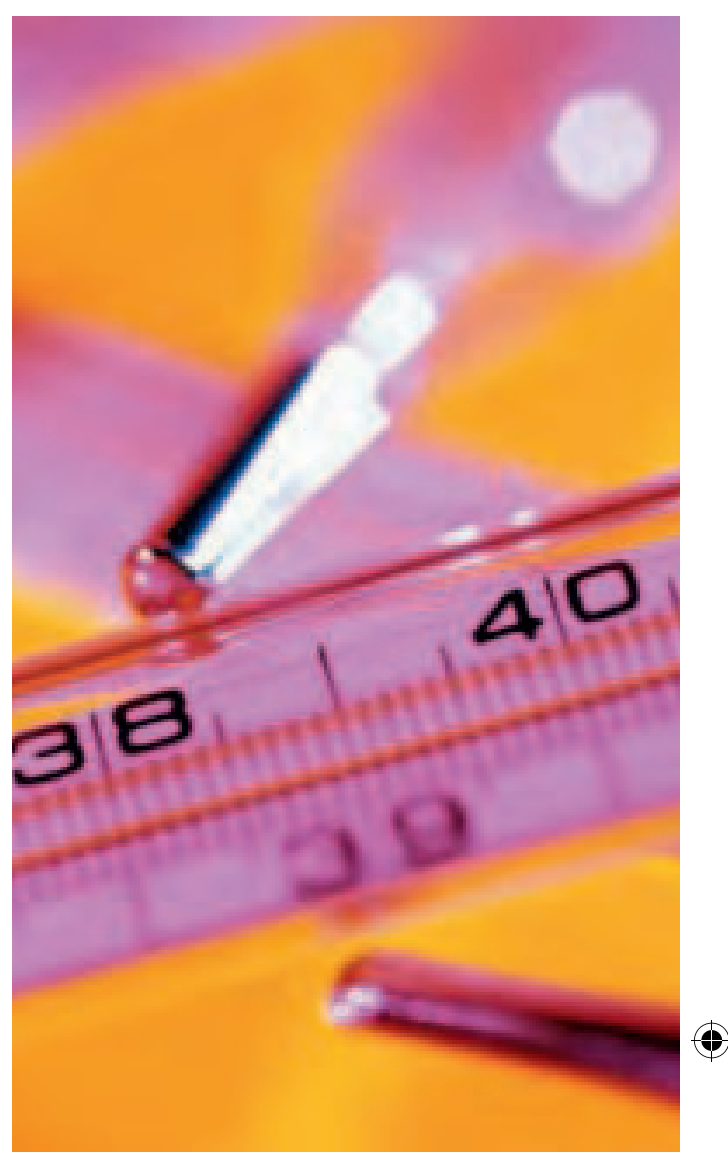

38,0 I TEMPERATUR: Har vedkommende feber, eller finnes det andre forklaringer? Foto: Colourbox

\section{Oppskrift på standardavvik}

) ta kvadratrota av variansen

Resultat: Standardavviket

Både varians og standardavvik er mål for spredning. Begge vil - generelt - øke når spredningen øker.

Vi kan nå beskrive resultatene våre ved hjelp av to størrelser: gjennomsnittet og standardavviket. Og dette uavhengig av om vi har gjort ti eller titusen målinger.

Alle dyr er like, men noen dyr er mer like enn andre. Huxley 